\title{
Changes in progesterone secretion following treatment with transforming growth factor $\alpha$ (TGF- $\alpha$ ) during the follicular phase of the sheep oestrous cycle
}

\author{
J. F. Murray ${ }^{1 *}$, J. A. Downing ${ }^{2}$, G. Evans ${ }^{1}$, J. K. Findlay ${ }^{3}$ and \\ R. J. Scaramuzzi ${ }^{2 *}$ \\ ${ }^{1}$ Department of Animal Science, The University of Sydney, Sydney, New South Wales, 2006, Australia; \\ ${ }^{2}$ CSIRO, Division of Animal Production, Blacktown, New South Wales, 2148, Australia; and ${ }^{3}$ Prince \\ Henry's Institute of Medical Research, PO Box 152, Clayton, Victoria, 3168, Australia
}

\begin{abstract}
The effects of transforming growth factor $\alpha$ (TGF- $\alpha$ ) on ovarian steroid secretion were investigated. Three crossbred ewes synchronized for oestrus with ovarian autotransplants were infused with TGF- $\alpha$ ( $30 \mu \mathrm{g}$ in $12 \mathrm{~h}$ ) via the ovarian artery for $12 \mathrm{~h}$ before withdrawal of progestagen pessary. Three ewes were used as controls. Jugular and ovarian venous blood samples were taken at intervals of $10 \mathrm{~min}$ at two stages during the follicular phase (21-27 $\mathrm{h}$ and $38-42 \mathrm{~h}$ after pessary withdrawal) and every $2 \mathrm{~h}$ from 44 to $86 \mathrm{~h}$. Plasma $\mathrm{LH}$ and FSH concentrations, and ovarian secretion rates of inhibin, androstenedione, oestradiol and progesterone were determined using radioimmunoassays. LH pulse amplitude increased in ewes treated with TGF- $\alpha$ in the early follicular phase $\left(0.92 \pm 0.25 \mu \mathrm{g} \mathrm{l}^{-1}\right.$ in controls versus $3.10 \pm 0.35 \mu \mathrm{g} \mathrm{l}^{-1}$ in TGF- $\alpha$ treated ewes; $\left.P<0.05\right)$ and remained high in the late follicular phase. Plasma FSH concentrations were high during the follicular phase in ewes treated with TGF- $\alpha(P<0.05)$. The infusion of TGF- $\alpha$ had no significant effect on the ovarian rate of secretion of androstenedione and, although the secretion rates of oestradiol and inhibin were consistently lower in TGF- $\alpha$-infused ewes, the differences were not significant. The ratio of secretion of androstenedione to oestradiol was greater during the follicular phase in TGF- $\alpha$-treated ewes $(P<0.05)$, suggesting that the efficiency of aromatization had been impaired. Progesterone secretion was enhanced by treatment with TGF- $\alpha$; progesterone secretion was detectable $52 \mathrm{~h}$ and $24 \mathrm{~h}$ after pessary withdrawal and had reached a secretion rate of $16.4 \pm 17.4 \mathrm{ng} \mathrm{min}^{-1}$ and $119.6 \pm 21.9 \mathrm{ng} \mathrm{min}^{-1}$ by $86 \mathrm{~h}$ after pessary withdrawal in control and TGF- $\alpha$-treated ewes, respectively. An increase in progesterone secretion would suggest that TGF- $\alpha$ had induced either premature luteinization or atresia in the large antral follicles.
\end{abstract}

\section{Introduction}

Transforming growth factor $\alpha$ (TGF- $\alpha$ ) is functionally similar to epidermal growth factor (EGF) and binds to EGF-binding sites with high affinity (Marquardt et al., 1984). TGF- $\alpha$ is the product of a gene that is separate and independent of that encoding EGF. Pre-pro-EGF mRNA has been identified in mouse ovarian tissue (Rall et al., 1985) but the presence of pre-pro-EGF or EGF mRNA has yet to be detected in the ovarian tissue of any other species. However, an EGF-like substance has been identified among the proteins secreted by rat interstitial or thecal cell preparations that, although biochemically and immunologically different from EGF, will bind to the EGF-binding sites found in the ovary and will also elicit similar responses to EGF (Skinner

*Current address: Department of Basic Sciences, Royal Veterinary College, University of London, Royal College Street, London, NWI OTU, UK. Revised manuscript received I March 1994. et al., 1987). EGF-like activity has also been demonstrated in the follicular fluid of porcine follicles (Hsu et al., 1987). Unlike EGF, expression of the gene encoding TGF- $\alpha$ has been detected in the theca cells of bovine (Skinner and Coffey, 1988) and rat (Kudlow et al., 1987) follicles but not in granulosa cells. TGF- $\alpha$ binds to EGF-binding sites in both the theca and granulosa cells where it elicits EGF-like effects (Adashi et al., 1987; Skinner and Coffey, 1988). It is therefore possible that the EGF-like activity observed in rat and pig follicles is attributable to TGF- $\alpha$ and that TGF- $\alpha$ is the endogenous ligand of ovarian EGF-binding sites.

Altematively, both EGF and TGF- $\alpha$ may be present in ovarian tissue and compete for the same binding sites. Immunoreactive EGF has been detected in ovarian follicles of women using an antiserum that has no crossreactivity with rat TGF- $\alpha$ (Westergard et al., 1990). Antisera raised against mouse or human EGF appear to have little crossreactivity in heterologous assays (Gregory et al., 1979). The clones that have been 
used so far as probes to identify expression of the gene encoding EGF in ovarian tissue of domestic species may also be too species specific to be effective in heterologous tissue. A portion of the gene encoding pig EGF has been isolated and characterized (Pascall et al., 1991) and differences between the pig and human sequences were observed.

The possibility that genes encoding both EGF and TGF- $\alpha$ occur in ovarian tissue of domestic species is strong. If both are present in the ovary then it would be reasonable to assume that they have individual roles in ovarian function and may elicit different effects on steroid and inhibin secretion. This experiment was designed to investigate the effects of TGF- $\alpha$ on ovarian steroid and inhibin secretion in vivo during the follicular phase of the sheep oestrous cycle, and to determine whether it elicits the same effects as EGF in vivo (Murray et al., 1993).

\section{Materials and Methods}

\section{Animals and experimental design}

The experiment was conducted in May 1988 at Prospect, New South Wales, Australia $\left(34^{\circ} \mathrm{S}\right)$. Border Leicester $\times$ Merino ewes $(n=6)$ with ovarian autotransplants (Goding et al., 1967) were randomly allocated to one of two groups. The autotransplanted ovaries of three ewes were infused, via the ovarian artery, with approximately $30 \mu \mathrm{g}$ human TGF- $\alpha$ (Sigma Chemical Co., St Louis, MO) for $12 \mathrm{~h}$. The remaining three ewes not infused with TGF- $\alpha$ were controls.

After being injected i.m. with a synthetic prostaglandin (125 $\mathrm{gg}$ Estrumate: ICI, Sydney), all ewes were treated with a progestagen pessary for 12 days (medroxy acetate progestagen; Repromap: Upjohn, Rydalmere). Ewes were infused with TGF- $\alpha$ for $12 \mathrm{~h}$ before the removal of the progestagen pessary, and another $125 \mu \mathrm{g}$ of synthetic prostaglandin was injected i.m. to induce luteolysis. The ewes were infused at this time because it is considered that the follicle(s) destined to ovulate is derived from the pool of antral follicles that are $\geqslant 2.0 \mathrm{~mm}$ in diameter, which are present at the time of luteolysis (Land, 1973; Tsonis et al., 1984).

\section{Infusions}

Human TGF- $\alpha$ was dissolved in non-pyrogenic sterile saline ( $9 \mathrm{~g} \mathrm{NaCl} \mathrm{l}^{-1}$; Travenol Laboratories, Old Toongabbie, NSW). The autotransplanted ovary was infused with $30 \mu \mathrm{g}$ TGF- $\alpha$ for the total $12 \mathrm{~h}$ of infusion. [Originally, the dose chosen was $60 \mu \mathrm{g}$ human TGF- $\alpha$ for $12 \mathrm{~h}$, so that the results of this study could be compared with a similar experiment using EGF (Murray ef al., 1993). However, because TGF- $\alpha$ is expensive, a lower dose was administered.] The method of infusion via the ovarian artery has been described by McCracken ef al. (1969). Control ewes were not infused with $0.9 \%(w / v) ~ \mathrm{NaCl}$ because it was known to have no effect on ovarian blood flow or ovarian steroid secretion (McCracken et al., 1969).

\section{Collection of blood samples}

At the end of the infusion period (referred to as $0 \mathrm{~h}$ ) the progestagen pessaries were withdrawn and prostaglandin was administered. Peripheral and ovarian blood samples were taken at $3 \mathrm{~h}$ intervals from $12 \mathrm{~h}$ after pessary withdrawal until a period of intensive sampling beginning $21 \mathrm{~h}$ after pessary withdrawal. The samples taken at $10 \mathrm{~min}$ intervals from 21 to $27 \mathrm{~h}$ after pessary withdrawal were taken during the early follicular phase. No blood samples were taken between 27 and $38 \mathrm{~h}$. A second period of intensive sampling was performed between 38 and $42 \mathrm{~h}$ after pessary withdrawal (late follicular phase). Monitoring by sampling continued after the second intensive sampling period at $2 \mathrm{~h}$ intervals up to $86 \mathrm{~h}$ after pessary withdrawal.

\section{Radioimmunoassays}

The concentrations of LH and FSH in jugular venous plasma were determined using radioimmunoassays described by Murray et al. (1993). The sensitivity of the LH assay was $0.2 \mu \mathrm{g} \mathrm{l}^{-1}$ and the intra-assay and interassay coefficients of variation for a quality control of medium concentration were $8.1 \%$ and $3.4 \%$, respectively. The FSH assay had a sensitivity of $0.06 \mu \mathrm{g} \mathrm{I}^{-1}$ and the intra-assay and interassay coefficients of variation for a quality control of medium concentration were $14.6 \%$ and $11.4 \%$, respectively. The concentrations of androstenedione, oestradiol and progesterone in ovarian venous plasma were determined by radioimmunoassays (Scaramuzzi et al., 1975; Campbell, 1988). The sensitivities of the androstenedione, oestradiol and progesterone radioimmunoassays were 13.9, 9.9 and 8.0 pmol per tube (i.e. $4.0,2.7$ and 2.5 pg per tube), respectively. The intra-assay and interassay coefficients of variation for androstenedione, oestradiol and progesterone were $10.1 \%$ and $12.5 \%, 3.2 \%$ and $11.9 \%$, and $12.9 \%$ and $3.7 \%$, respectively, for quality controls of medium range concentration. Inhibin concentrations in ovarian and jugular venous plasma samples were determined using a doubleantibody radioimmunoassay (Murray et al., 1993). The sensitivity of the assay was $50.0 \mathrm{ng} \mathrm{l}^{-1}$. Intra-assay and interassay coefficients of variation were $7.2 \%$ and $12.6 \%$, respectively, for a quality control of medium range concentration. This assay is defined as measuring immunoreactive inhibin because of the crossreactivity of the antibodies with the various forms of the $\alpha$ subunit, which may or may not be secreted by the sheep ovary. The jugular venous concentration of inhibin was subtracted from the concentration of inhibin in ovarian venous plasma before the secretion rate of inhibin by the ovary was calculated. The volume of each ovarian venous blood sample, the time taken to collect the sample and the packed cell volume were recorded and used to calculate the rate of secretion of the ovarian steroids and inhibin (Goding et al., 1967).

\section{Statistical analyses}

The manual selection option of MUNRO (Elsevier-Biosoft, Cambridge, UK), a pulse analysis program for the Apple Macintosh computer, was used to estimate the parameters of LH and steroid pulses during the early and late follicular phases of the oestrous cycle. The parameters estimated were pulse interval, pulse amplitude and the nadir (basal concentration or secretion rate). A pulse was defined as described by Backstrom et al. (1982); that is, if the values of two consecutive samples 
Table 1. Peripheral plasma LH concentrations, values for the parameters of LH pulsatile secretion and the ovarian secretion rates of androstenedione, oestradiol and inhibin during the early (21-27 h after pessary withdrawal) and late (38-42 h) follicular phases in control ewes $(n=3)$ and in ewes infused, via the ovarian artery, with transforming growth factor $\alpha($ TGF- $\alpha, n=3)$

\begin{tabular}{|c|c|c|c|c|}
\hline \multirow[b]{2}{*}{ Parameter } & \multicolumn{2}{|c|}{ Early follicular phase } & \multicolumn{2}{|c|}{ Late follicular phase } \\
\hline & Control & TGF- $\alpha$ & Control & TGF- $\alpha$ \\
\hline \multicolumn{5}{|l|}{$\mathrm{LH}$} \\
\hline Concentration $\left(\mu \mathrm{g} \mathrm{l}^{-1}\right)$ & $0.76 \pm 0.04$ & $2.07 \pm 0.14^{*}$ & $0.61 \pm 0.04$ & $1.79 \pm 0.12 *$ \\
\hline Pulse amplitude $\left(\mu \mathrm{g} \mathrm{l}^{-1}\right)$ & $0.92 \pm 0.25$ & $3.10 \pm 0.35^{*}$ & $0.63 \pm 0.16$ & $2.28 \pm 0.69^{*}$ \\
\hline Nadir $\left(\mu \mathrm{gl}^{-1}\right)$ & $0.45 \pm 0.06$ & $1.14 \pm 0.33$ & $0.42 \pm 0.13$ & $1.08 \pm 0.12$ \\
\hline Pulse interval (min) & $65.5 \pm 12.28$ & $66.1 \pm 9.9$ & $59.2 \pm 10.8$ & $57.8 \pm 8.9$ \\
\hline \multicolumn{5}{|l|}{ Androstenedione } \\
\hline Secretion rate $\left(\mathrm{ng}_{\min }^{-1}\right)$ & $5.8 \pm 0.5$ & $8.1 \pm 0.5$ & $5.1 \pm 0.6$ & $8.9 \pm 0.7$ \\
\hline \multicolumn{5}{|l|}{ Oestradiol } \\
\hline Secretion rate $\left(\mathrm{ng} \mathrm{min}^{-1}\right)$ & $5.0 \pm 0.4$ & $3.4 \pm 0.3$ & $6.2 \pm 0.6$ & $4.5 \pm 0.4$ \\
\hline Inhibin & & & & $\pi T-7+\pi$ \\
\hline Secretion rate $\left(\mathrm{ng} \min ^{-1}\right)$ & $11.3 \pm 0.5$ & $6.8 \pm 0.9$ & $13.9 \pm 0.5$ & $11.7 \pm 1.7$ \\
\hline
\end{tabular}

Values are means \pm SEM.

*Significantly different from paired control $(P<0.05)$.

were greater than the mean of the two preceding samples, and if at least one of these samples was three or more times the intra-assay coefficient of variation of the assay greater than the nadir, then the increase in hormone concentration or secretion rate was considered to be a pulse. Differences between treatment groups and within treatment groups between phases for the parameters of $\mathrm{LH}$ pulsatile secretion, mean $\mathrm{LH}$ and FSH concentrations and ovarian steroid and inhibin secretion rates during the two intensive sampling periods were determined by analysis of variance using GENSTAT (Mark 4.03; Numerical Algorithms Group Ltd).

\section{Results}

\section{General observations}

Ewe 5 exhibited muscle tremors during the first $2 \mathrm{~h}$ of infusion with TGF- $\alpha$. Ewes 22 and 25, also treated with TGF- $\alpha$, had a reduced appetite during the infusion period but regained their appetites soon after the infusions ended.

\section{Plasma $L H$ concentrations}

The mean concentration of LH in peripheral plasma during the early and late follicular phases was significantly greater in ewes infused with TGF- $\alpha$ than in controls $(P<0.05$; Table 1 , and Figs 1 and 2). Within a treatment group there was no effect on $\mathrm{LH}$ secretion owing to the stage of the follicular phase. The increase in the mean plasma LH concentration in TGF- $\alpha$-treated ewes was a function of the increase in LH pulse amplitude in the treated ewes $(P<0.05$; Table 1 , and Figs 1 and 2$)$. There were no differences in either nadir or pulse interval of $\mathrm{LH}$ between controls and TGF- $\alpha$-treated ewes during either the early or late follicular phases (Table 1).

A preovulatory LH surge of $\geqslant 25 \mathrm{~g} \mathrm{I}^{-1}$ was observed in each control animal within the $86 \mathrm{~h}$ sampling period; that is,
Ewes 2, 7 and 8 exhibited preovulatory LH surges commencing at 84,52 and $80 \mathrm{~h}$ after pessary withdrawal, respectively. Two of the three ewes treated with TGF- $\alpha$ exhibited LH surges of $\geqslant 20 \mu \mathrm{g} \mathrm{I}^{-1}$ within the sampling period (Ewes 5 and 22 exhibited preovulatory LH surges at 72 and $56 \mathrm{~h}$ after pessary withdrawal, respectively). The third ewe receiving TGF- $\alpha$ treatment (Ewe 25) did not exhibit a preovulatory LH surge within the $86 \mathrm{~h}$ sampling period. There appeared to be no relation between the time of the preovulatory $\mathrm{LH}$ surge with respect to the time of pessary withdrawal and the cessation of treatment.

\section{Plasma FSH concentrations}

The mean concentration of $\mathrm{FSH}$ in peripheral plasma was significantly greater in the ewes that had received infusions of TGF- $\alpha$ than in controls during the early $\left(0.31 \pm 0.01 \mu \mathrm{g} \mathrm{I}^{-1}\right.$ in controls versus $1.39 \pm 0.05 \mu \mathrm{g} \mathrm{l}^{-1}$ in TGF- $\alpha$-treated ewes; $P<0.05)$ and late $\left(0.42 \pm 0.03 \mu \mathrm{g} \mathrm{I}^{-1}\right.$ in controls versus $2.07 \pm 0.13 \mu \mathrm{g} \mathrm{l}^{-1}$ in TGF- $\alpha$-treated ewes; $P<0.01$ ) follicular phase sampling periods (Figs 1 and 2). There were no differences in the plasma FSH concentrations within a treatment between the early and late follicular phases.

A rise in the plasma concentration of FSH was associated with the LH surge in all ewes in which a preovulatory LH surge occurred. In Ewe 25, which did not have a preovulatory LH surge within the $86 \mathrm{~h}$ of sampling, FSH concentrations had declined from the high values measured in the late follicular phase to control values by the end of the $86 \mathrm{~h}$ sampling period.

\section{Androstenedione and oestradiol secretion rates}

In both the early and late follicular phases there were no significant differences in the mean secretion rates for either androstenedione or oestradiol between control and TGF- $\alpha$ treated ewes (Table 1 , and Figs 1 and 2), but the secretion rate 


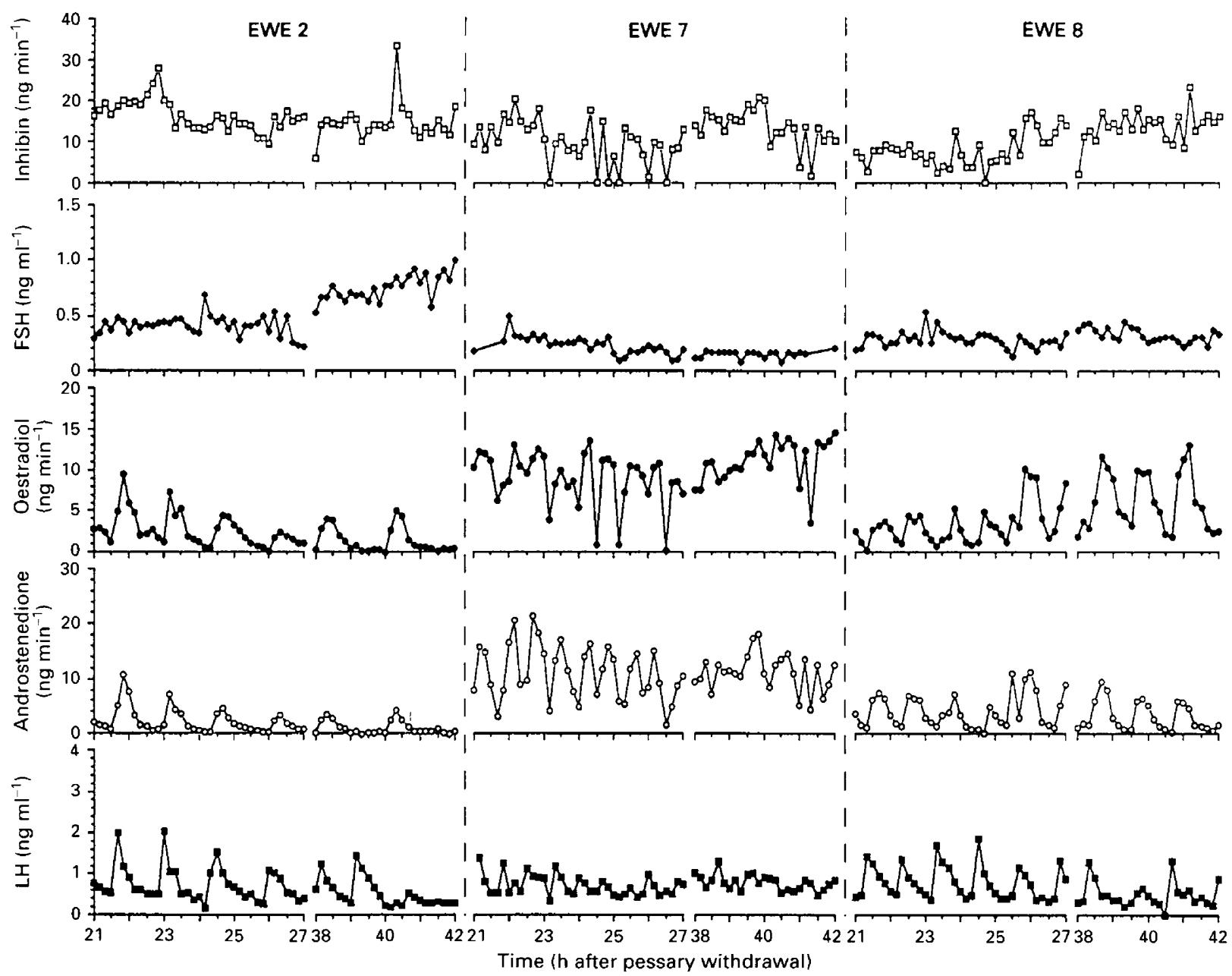

Fig. 1. Circulating pituitary gonadotrophin concentrations and ovarian steroid and inhibin secretion rates during the early $(21-27 \mathrm{~h}$ after pessary withdrawal) and late $(38-42 \mathrm{~h})$ follicular phases in the three control ewes.

of oestradiol was consistently lower in TGF- $\alpha$-infused ewes and the pulsatile response of oestradiol to $\mathrm{LH}$ appeared to be reduced (Fig. 2). Both androstenedione and oestradiol secretion appeared to be suppressed in Ewe 25 (Fig. 2). The ratio of the mean secretion rate of androstenedione to oestradiol was calculated for each group and there were significant differences between the two treatment groups. In the early follicular phase the ratio was significantly lower in control ewes compared with ewes treated with TGF- $\alpha$ ( $1.1 \pm 0.1$ in control versus $2.5 \pm 0.1$ in TGF- $\alpha$-treated ewes; $P<0.05$ ); although this ratio had decreased in the late follicular phase in both control and TGF- $\alpha$-treated ewes, it was still greater in ewes treated with TGF- $\alpha(0.7 \pm 0.3$ in controls versus $1.9 \pm 0.2$ in TGF- $\alpha$-treated ewes; $P<0.07$ ).

\section{Inhibin secretion rates}

There was no significant difference in inhibin secretion between control and TGF- $\alpha$-treated ewes during the early and late follicular phases (Table 1 , and Figs 1 and 2). Inhibin secretion in Ewe 25, a ewe treated with TGF- $\alpha$, was effectively suppressed (Fig. 2).

\section{Progesterone secretion}

Progesterone secretion was very low and only detectable $52 \mathrm{~h}$ after the end of the infusion period in ovarian venous plasma in control ewes during the period of sampling that followed the withdrawal of the progestagen pessary (Fig. 3). In contrast, a significant rate of progesterone secretion was detected within $24 \mathrm{~h}$ of the completion of the infusions and pessary withdrawal in ewes treated with TGF- $\alpha$ (Fig. 3). At the end of the experiment, $86 \mathrm{~h}$ after pessary withdrawal, progesterone secretion had reached the mean rate of $119.6 \pm 21.9 \mathrm{ng} \mathrm{min}^{-1}$ in TGF- $\alpha$-treated ewes (compared with $16.4 \pm 17.4 \mathrm{ng} \mathrm{min}^{-1}$ for control ewes).

\section{Discussion}

TGF- $\alpha$ appears to act directly on the sheep ovary to enhance progesterone secretion. Although there were no significant differences in the ovarian secretion rates of androstenedione and oestradiol following treatment with TGF- $\alpha$, there were significant differences in the ratio of androstenedione to oestradiol secretion between control and TGF- $\alpha$-treated ewes, 


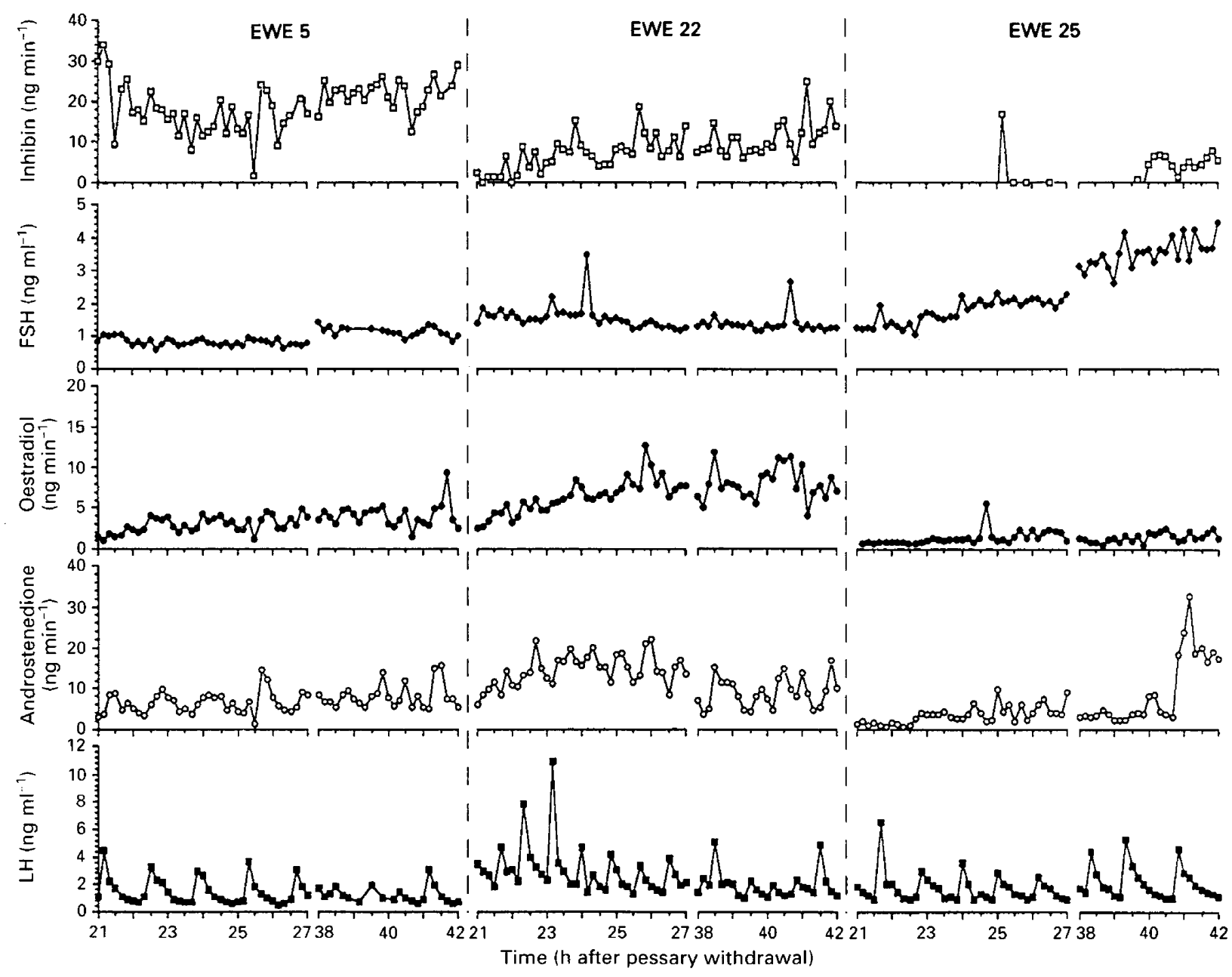

Fig. 2. Circulating pituitary gonadotrophin concentrations and ovarian steroid and inhibin secretion rates during the early $(21-27 \mathrm{~h}$ after pessary withdrawal) and late $(38-42 \mathrm{~h}$ ) follicular phases in the three ewes infused with transforming growth factor $\alpha$. Ewe 25 did not have an LH surge during the $86 \mathrm{~h}$ sampling period. (Note that the units of some of the $y$ axes are different from those in Fig. 1.)

which implies that the efficiency of aromatization had been impaired by TGF- $\alpha$ treatment. There was no significant effect of TGF- $\alpha$ on ovarian inhibin secretion. Associated with the direct action of TGF- $\alpha$ on the ovary was a concomitant increase in LH pulse amplitude and an increase in FSH secretion. The increases in gonadotrophin secretion following treatment with TGF- $\alpha$ are probably consequences of the disruption in normal ovarian function and not due to the direct action of TGF- $\alpha$ on the hypothalamo-pituitary axis.

Progesterone secretion is usually very low, if at all detectable in ovarian venous plasma during the late follicular phase and remains so up to $15 \mathrm{~h}$ after oestrus (Bjersing et al., 1972). In control ewes, progesterone secretion was undetectable to very low throughout the sampling period, as expected. However, in ewes treated with TGF- $\alpha$, progesterone secretion was detectable within $24 \mathrm{~h}$ after the infusion period. The rise in progesterone production, therefore, preceded the preovulatory LH surge by at least $36 \mathrm{~h}$. When the autotransplanted ovary was infused with $60 \mu \mathrm{g}$ of EGF over $12 \mathrm{~h}$ before progestagen pessary withdrawal, oestradiol and inhibin secretion were

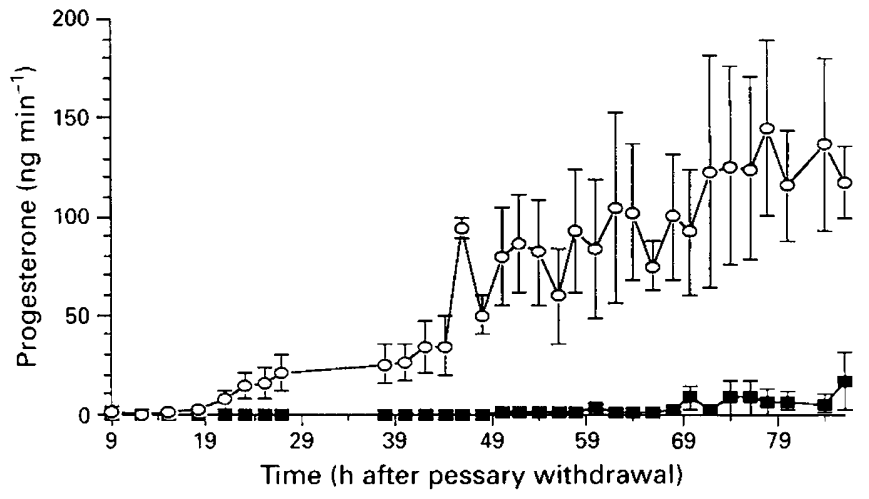

Fig. 3. Secretion rates of ovarian progesterone (mean \pm SEM) in control ewes $(n ; n=3)$ and in ewes treated with transforming growth factor $\alpha(\odot)$ during the follicular phase of the oestrous cycle.

completely suppressed and progesterone secretion was enhanced (Murray et al., 1993). The biological potencies of EGF and TGF- $\alpha$ used in these experiments are unknown, but $30 \mu \mathrm{g}$ 
of TGF- $\alpha$ could elicit the same pattern and magnitude of response in ovarian progesterone secretion as $60 \mu \mathrm{g}$ of EGF, although TGF- $\alpha$ did not have the same effects on the other ovarian steroids or inhibin as this amount of EGF. This would imply that TGF- $\alpha$ is the more potent stimulator of progesterone secretion.

Androstenedione and oestradiol secretion rates were not significantly affected during the follicular phase following treatment with TGF- $\alpha$. Although a lower dose of TGF- $\alpha$ was equipotent to EGF at enhancing progesterone secretion, the same dose did not result in an inhibition of oestradiol secretion, even though an inhibitory effect on oestrogen production by TGF- $\alpha$ has been demonstrated in cultured rat granulosa cells (Adashi and Resnick, 1986) and in ewes in vivo (Campbell et al., in press).

Treatment with TGF- $\alpha$ resulted in significant increases in the mean concentrations of both $\mathrm{LH}$ and FSH in peripheral plasma compared with controls. It is possible that TGF- $\alpha$ acted directly on the hypothalamo-pituitary axis to increase LH pulse amplitude and FSH secretion. Although the ovary was directly infused with TGF- $\alpha$ to eliminate the possible effects of TGF- $\alpha$ on the hypothalamo-pituitary axis, the amount of TGF- $\alpha$ taken up by the ovary is unknown, and the possibility that TGF- $\alpha$ acted directly on the hypothalamo-pituitary axis may not be completely excluded. However, the frequency of LH pulses was not significantly attenuated by the relatively high concentrations of circulating progesterone in TGF- $\alpha$-treated ewes and a surge of LH was still produced. Although the concentration of progesterone was relatively high, it was not comparable to that normally recorded during the luteal phase of the oestrous cycle when LH pulse frequency is decreased owing to the feedback of progesterone (Baird, 1978). The significant increase in plasma FSH concentrations observed in ewes treated with TGF- $\alpha$ did not stimulate oestradiol secretion even though aromatization has been shown to increase in ewes treated with FSH in vivo (McNatty et al., 1985), and there were no statistically significant differences in inhibin secretion rates between control and TGF- $\alpha$-treated ewes during the early and late follicular phases. Ewe 25 appears to have been more sensitive to the TGF- $\alpha$ treatment, as shown by the suppression of ovarian androstenedione, oestradiol and inhibin secretion, than either Ewe 5 or Ewe 22.

Ovarian examinations were not performed and so it is not known how TGF $\alpha$ affected the follicle population. Disruption of aromatization, which occurs when a large antral follicle undergoes either atresia or luteinization, would result in a decline in oestradiol secretion, which would in turn result in an increase in both LH and FSH secretion. The increase in FSH secretion before the preovulatory LH surge in the presence of increasing progesterone secretion suggests that the preovulatory follicle(s) had either begun to luteinize or had become atretic and that the concentration of FSH had increased to stimulate other antral follicles. If premature luteinization had occurred then the affected follicle(s) could not prevent a subsequent LH surge. An atretic antral follicle could also secrete a significant amount of progesterone in the presence of a high concentration of $\mathrm{LH}$, but it is not possible to distinguish between these two possible sources of progesterone secretion in this experiment. Using real-time ultrasound to monitor follicular growth in an autotransplanted ovary, Campbell et al. (in press) demonstrated a marked decline in the number of large follicles within $12 \mathrm{~h}$ after infusing $60 \mu \mathrm{g}$ TGF- $\alpha$ for $12 \mathrm{~h}$, and concluded that TGF- $\alpha$ treatment had induced atresia in the population of large follicles.

This experiment raises the important question as to which is the endogenous ligand for the EGF-like binding sites in the ovary. From these data we conclude that EGF is the more potent inhibitor of oestradiol and inhibin secretion, while TGF- $\alpha$ is the more potent enhancer of progesterone secretion. The actions of the two growth factors appear to be different and independent of dose. Further investigations are therefore necessary to determine whether both TGF- $\alpha$ and EGF have independent functions in ovarian function.

The authors thank K. J. Heasman and A. Souter (Department of Animal Science, The University of Sydney) for assistance with animal handling, D. Russell (Prince Henry's Institute, Melbourne) for technical assistance with the inhibin radioimmunoassay, A. Kirby (School of Crop Sciences, The University of Sydney) for statistical advice, A. S. McNeilly (MRC, Edinburgh) for oLH antiserum R29, the National Hormone and Pituitary Program (NIDDK, Baltimore, ML) for NIAMDD-anti-oFSH-I, and D. M. Robertson (Prince Henry's Institute, Melbourne) for both purified $31 \mathrm{kDa}$ bovine and $32 \mathrm{kDa}$ ovine inhibin. This work was supported by The Reserve Bank of Australia Rural Credits Development Fund and the National Health and Medical Research Council of Australia.

\section{References}

Adashi EY and Resnick CE (1986) Antagonistic interactions of transforming growth factors in the regulation of granulosa cell differentiation Endocrinology 119 1879-1881

Adashi EY, Resnick CE and Twardzik DR (1987) Transforming growth factor $\alpha$ attenuates the acquisition of aromatase activity by cultured rat granulosa cells Journal of Cellular Biochemistry 33 1-13

Backstrom CT, McNeilly AS, Leask RM and Baird DT (1982) Pulsatile secretion of LH, FSH, prolactin, oestradiol and progesterone during the menstrual cycle Clinical Endocrinology 17 29-42

Baird DT (1978) Pulsatile secretion of LH and ovarian oestradiol during the follicular phase of the sheep oestrous cycle Biology of Reproduction 18 359-364

Bjersing L, Hay MF, Kann G, Moor RM, Naftolin F, Scaramuzzi RJ, Short RV and Younglai EV (1972) Changes in gonadotrophins, ovarian steroids and follicular morphology in sheep at oestrus Journal of Endocrinology $\mathbf{5 2}$ $465-479$

Campbell BK (1988) Factors Affecting Ovulation Rate in Sheep and Cattle. PhD thesis, University of Sydney

Campbell BK, Gordon BM and Scaramuzzi RJ The effect of ovarian arterial infusion of transforming growth factor $\alpha$ on ovarian hormone secretion by ewes with an autotransplanted ovary Journal of Endocrinology (in press)

Goding JR, McCracken JA and Baird DT (1967) The study of ovarian function in the ewe by means of a vascular autotransplantation technique Journal of Endocrinology 39 37-52

Gregory H, Holmes JE and Willshire IR (1979) Urogastrone - epidermal growth factor. In Methods of Hormone Radioimmunoassay (2nd Edn) pp 927-939 Eds BM Jaffe and HR Behrman. Academic Press, New York

Hsu C-J, Holmes SD and Hammond JM (1987) Ovarian epidermal growth factor-like activity concentrations in porcine follicular fluid during follicular enlargement Biochemical and Biophysical Research Communications 147 242-247

Kudlow JE, Kobrin MS, Purchio AF, Twardzik DR, Hernandez ER, Asa SL and Adashi EY (1987) Ovarian transforming growth factor- $\alpha$ gene expression: immunohistochemical localization to the theca-interstitial cells Endocrinology 121 1577-1579

Land RB (1973) Ovulation rate of Finn-Dorset sheep following unilateral ovariectomy or chlorpromazine treatment at different stages of the oestrous cycle Journal of Reproduction and Fertility 33 99-105 
McCracken JA, Uno A, Goding JR, Ichikawa $Y$ and Baird DT (1969) The in vivo effects of sheep pituitary gonadotrophins on the secretion of steroids by the autotransplanted ovary of the ewe Journal of Endocrinology $\mathbf{4 5}$ 425-440

McNatty KP, Hudson N, Gibb M, Ball K, Henderson KM, Heath DA, Lun S and Kieboom LE (1985) FSH influences follicle viability, oestradiol biosynthesis and ovulation rate in Romney ewes Journal of Reproduction and Fertility $\mathbf{7 5}$ $121-131$

Marquardt H, Hunkapiller MW, Hood LE and Todaro GJ (1984) Rat transforming growth factor type I: structure and relation to epidermal growth factor Science 223 1079-1082

Murray JF, Downing JA, Evans G, Findlay JK and Scaramuzzi RJ (1993) Epidermal growth factor acts directly on the ovary in vivo to inhibit oestradiol and inhibin secretion and enhance progesterone secretion in the sheep Joumal of Endocrinology $137253-264$

Pascall JC, Jones DSC, Doel SM, Clements JM, Hunter M, Fallon T, Edwards M and Brown KD (1991) Cloning and characterization of a gene encoding pig epidermal growth factor Joumal of Molecular Endocrinology 6 63-70
Rall LB, Scott J, Bell GI, Crawford RJ, Penschow JD, Niall HD and Coghlan JP (1985) Mouse prepro-epidermal growth factor synthesis by the kidney and other tissues Nature 313 228-231

Scaramuzzi RJ, Corker CS, Young G and Baird DT (1975) Production of antisera to steroid hormones in sheep. In Steroid Immunoassay pp 111-122 Eds EHD Cameron, SG Hillier and K Griffiths. Alpha Omega Alpha Publishing, Cardiff

Skinner MK and Coffey RJ, Jr (1988) Regulation of ovarian cell growth through the local production of transforming growth factor- $\alpha$ by theca cells Endocrinology 123 2632-2638

Skinner MK, Lobb D and Dorrington JH (1987) Ovarian thecal/interstitial cells produce an epidermal growth factor-like substance Endocrinology 121 1892-1899

Tsonis CG, Cahill LP, Carson RS and Findlay JK (1984) Identification at the onset of luteolysis of follicles capable of ovulation in the ewe Journal of Reproduction and Fertility 70 609-614

Westergard LG, Yding Andersen C and Byskov AG (1990) Epidermal growth factor in small antral ovarian follicles of pregnant women Journal of Endocrinology $127363-367$ 